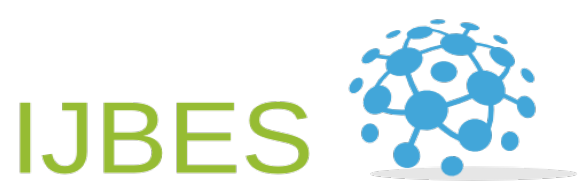

Business Ecosystem \& Strategy

BRSS VOL 1 NO 2 ISSN: 2687-2293

\title{
An insight for the market driving forces: Case of Tesla Model- $\mathbf{S}$
}

\author{
Doaa M. Salman Abdou ${ }^{a^{*}}$ \\ Crossref \\ ${ }^{a}$ Professor of Economics and Finance, Head of economics department, Associate Dean, October University for Modern Sciences and Arts, Egypt
}

\begin{tabular}{l} 
A R T I C L E IN F O \\
\hline Article history: \\
Received 12 August 19 \\
Received in revised form 22 Sept 19 \\
Accepted 07 October19 \\
\hline Keywords: \\
CEO \\
Market forces \\
Electric cars \\
Environment impact \\
JEL Classification: \\
A11, D43
\end{tabular}

\begin{abstract}
A B S T R A C T
Market analysis is a diagnostic process to uncover the root causes of how markets perform from an economic perspective. This market analysis will help us understand how the market supply and demand work and what elements affect this performance during 2015-2017. Market analysis provides the initial foundation for the market intervention; this foundation is not constant as markets that are constantly evolving and dynamic. This paper will analyze the factors that affect the supply and demand in the same period in addition to the price elasticity for the Tesla Model-S. Finally, this paper develops an insight into the future of the industry.
\end{abstract}

C 2019 Bussecon International Academy. Hosting by Bussecon International. All rights reserved. Peer review under responsibility of Bussecon International Academy.

\section{Introduction}

Market structure is very important for implementation of adaptive business strategies in competitive environment. Competitive strategies in business ecosystem should be effective and well designed. Market structures portrays the competitive environment in which a company/firm operates. Competitive strategies that are implemented by a firm in a market are affected by the characteristics of the market structure itself. Tesla Motors (Tesla) is a global enterprise that designs, produces and markets for electric powered vehicles (EV) and its components e.g. battery packs, and Powertrains. The overarching purpose of Tesla is to expedite the move from a mine-and-burn hydrocarbon economy towards a sustainable, solar electric economy. A group of engineers in Palo Alto, USA founded the company in 2003. The Name "Tesla" originated in memory of Nikola Tesla, who first built and patented an electrical induction motor in 1888 (Tesla Motors, Inc.). The firm is currently the only vehicle manufacturer selling zero- emission sports cars in serial production. On March 17th 2008, Tesla started the mass production of the first model Tesla Roadster, a solely electric operated sports car. On January 12th 2010, Tesla sold his 1000th Roadster, Somssich, E. (2017).

Thereafter Tesla used its technological advantage and expanded to the luxury sedan market leading to the introduction of their second EV. Recently, Tesla produces a top-selling luxury car and has a market capitalization twice that of Fiat Chrysler and half that of General Motors or Ford. Tesla has shown that a start-up can enter and disrupt the status quo in one of the most established industries ( Holdway et al, 2010; Sun, 2010)

Tesla Model-S: Only two of Tesla's cars have hit the road-Roadster and Model-S. Roadster was more of a limited edition and was sold out by 2012. Since then, Tesla has offered Model-S, having sold more than 50,000 units so far, Tesla vehicles have received excellent reviews from their customers. The innovative features in Tesla makes it an aspirational car. To add to that, Tesla has received the highest safety ratings from the National Highway Traffic Safety Administration. In fact, Tesla is placed against luxury carmakers ( Kessler 2015).

\footnotetext{
* Corresponding author. Tel.: +0-20-1006-179-666; ORCID ID: 0000-0001-5050-6104

Peer review under responsibility of Bussecon International Academy.

(C) 2019 Bussecon International. Hosting by Bussecon International. All rights reserved.

http://dx.doi.org/10.36096/ijbes.v1i2.123
} 
Tesla's solar panels are blend into its roof with integrated front circuits and no visible mounting hardware. The result is a clean, streamlined look, Palin, R. et al, 2012. Tesla charges with energy produced by solar panels, making that energy available when needed, day or night, the Powerwall also enables solar panels to produce energy during grid outages. Tesla's solar roof: Customizing the amount of electricity the Solar Roof produces to fit energy needs. Tesla was ranked as the world's bestselling plug-in passenger car manufacturer in 2018 , both as a brand and by automotive group, with 245,240 units delivered and a market share of $12 \%$ of the plug-in segment sales.

This paper focuses on the reasons for accelerating the demand for using electric cars, despite that the environmental benefit of electric cars is still unclear on the macro level.

The following sections will focus on the market analysis and the successful driving forces followed by a conclusion and the future expected challenges.

\section{Literature Review}

Since traditional market share protection tactics discourage competitors from entering the market, product locking and offering lower rates can also prevent businesses from growing. The idea of lowering the usage of fossil fuel was firstly adopted by Tesla Motors as they stated that electric cars are much stronger than oil-burning cars as EVs are more efficient plus environmental clean. Other car companies started recently to adopt the same idea and entered the EV market.

The market of electric cars is specified as an oligopoly market as there are only a certain number of players that controls the market. Parmar et al. (2017) stated that Tesla motors positioned itself in the market as the features that they offer is not available entirely in any of the large luxury automobile companies, however a few numbers of the famous automobile companies entered the market recently. The electric vehicles industry (EV) competition is intensive, and increasing regulatory standards, pressure manufactures to reduce vehicle emissions.

According to Parmar, Tesla's has the superior hand as it products revolve around its core competency of creating entirely electric cars. Tesla through the strong brand awareness already created through traditional markets. As they have a greater number of dealerships through the US. However, Tesla's have greater profits to invest in marketing and advertising campaigns. According to Statista, Tesla's Model 3 has an EV market share about of $60 \%$ as Model 3 is the most produced and sold electric car model in the US with similarly priced BMW, Benz and Audi fossil-fuel rivals. As the market of EV is oligopoly, which means that the company has the total ability to satisfy the market needs, therefore this supplier sets the price of its product and has the upper hand over the market and the barriers. According to Dragasevic, Rakocevic \& Glisevic, (2011), the game theory is an economic game that has two conditions, one being when competitors work together and form a cartel that is illegal in certain countries. Nevertheless, the way that one of the partners tends to deceive other by producing more than what they agreed is not always successful and eventually the deceiver gains a significantly greater share of the market than the others.

The other prerequisite is when companies on the market do not cooperate to increase competition and to reduce profits. According to the economist, the market of EV became highly competitive the last couple of years, but Tesla's is still leading the way as they got the higher market share than other firms. Cheong, Song, Hu, (2015) showed that, Competition is a business strategy focused on the mutual synthesis of collaboration and rivalry, which enables all competing firms to benefit, depending on their individual interests and goals, in terms of larger market shares, higher profits and technological progress. In reality coopetition is a kind of positive-sum game in which each player's final gains are better than what every player originally carries into the match. In addition to the game in which the winner takes every victory and the loser gets no defeat.

The co-patient system, the vertical or horizontal supply chain method, may contribute to reciprocal performance. A joint partnership between manufacturers and assemblers is a vertical supply chain co-operation. The significant demand for the product of an assembler on the retail market has resulted in more suppliers ' orders of parts. The major player in this industry are Tesla which offers hightech parts and safer vehicles, Toyota that has substantial vehicle shares but are new in the EV market, and finally BMW, and Mercedes-Benz that offer luxury and also focusing on producing cars that work on gasoline and electricity( Boyd \& Mellman, 1980). Moreover, the main challenge for the manufacturers are the consumers behavior about the new technology. According to Gayathree, \& Samarasinghe (2019), the main purpose of perceived risks concept is to understand these consumers behavior that includes five dimensions which help firms to understand the risks entirely.

The consumers' uncertainty about the technology of electric cars has a negative impact on purchase intention. Social risks identified as to what extent a consumer understands the importance of whether they think the technical service should be used by others.

\section{Research and Methodology}

Using the data for model S for the units sold and produced to describe the relation with the market forces and calculate the elasticity based on data from the company's financial analysis reports for the period between third quarter in 2015 till the second quarter in 2017. This paper use the regression equation to test if the decision for buying the curve referred to the price or not during the period under study. 


\section{Emprical Data and Market Analysis}

Over the course of 2016, Tesla's share in the U.S. automotive market rose to 2\%. However, Tesla's Model 3 has a market share of about $60 \%$. Currently, Tesla is the market leader in battery-electric car sales for the United States. The global market for electric vehicles is estimated to increase to over 567 billion U.S. dollars by 2025; Meanwhile Tesla Model "S" has a market share of about $18 \%$ as in December 31, 2016

Luxury automobile industry can be seen as an oligopoly for several reasons. First, few firms control the majority of the market share. There are smaller firms in the market, but their market share in the industry is very small compared to those of dominant firms. Small companies generally lack the financial capital to launch a brand on a large scale which is one of the challenges for sustaining. Secondly, the barriers for entry in the industry are very high. Producing such luxury cars requires a massive amount of investment and extremely high operating cost preventing small firms from entering the race. Tesla's work in an oligopoly market which have a limited competition in which a few producers control the majority of the market share and typically produce homogenous products.

\section{Market Driving Forces}

The Tesla Model "S" is an all-electric five-door car, produced by Tesla, Inc., and was introduced on June 22nd 2012. As of April 23, 2019, the Model S Long Range has an EPA range of $490 \mathrm{~km}$, which is higher than any other electric car.

\section{Production Driving Forces}

Tesla currently produces more batteries in terms of $\mathrm{kWh}$ than all other car manufacturers combined. With the increased production of the Gig-factory, the cost of Tesla battery cells will decrease significantly, the battery cell was reduced from $200 \$$ per $\mathrm{kWh}$ to $100 \$$. Tesla's Giga-factory would reduce the production costs by $30 \%$ because of its dependence on the solar panels. Moreover, Tesla has the knowhow of producing the entire electric component for their vehicles. Selling patented electric powertrain components to other automakers, including Daimler and Toyota. Panasonic's battery cell production lines in Tesla's Giga factory in Sparks, Nevada, produce 2170 cells exclusively. Figure 1 shows the increasing trend for the production and the price of the car which is based on the cost is fluctuation due to many reasons.

First the company faces shortage of liquidity: In comparison to competitors like Ford which has 20 billion U.S. dollars, General Motors with 25 billion U.S. dollars or Fiat Chrysler Automobiles 40 billion U.S. dollars which are cash rich from years and years of operations. From the challenges as well, is the capacity Issues. Tesla manufactures cars in just one plant, which is located in Fremont, California. The plant has a capacity to make 500,000 vehicles and the maximum production of the company is limited to this figure making it difficult for the company to target higher volumes. From the future challenges is the high debit load: as Tesla has 5 billion U.S. dollars long-term debit in 2017 that will reflect on the future years' plans.

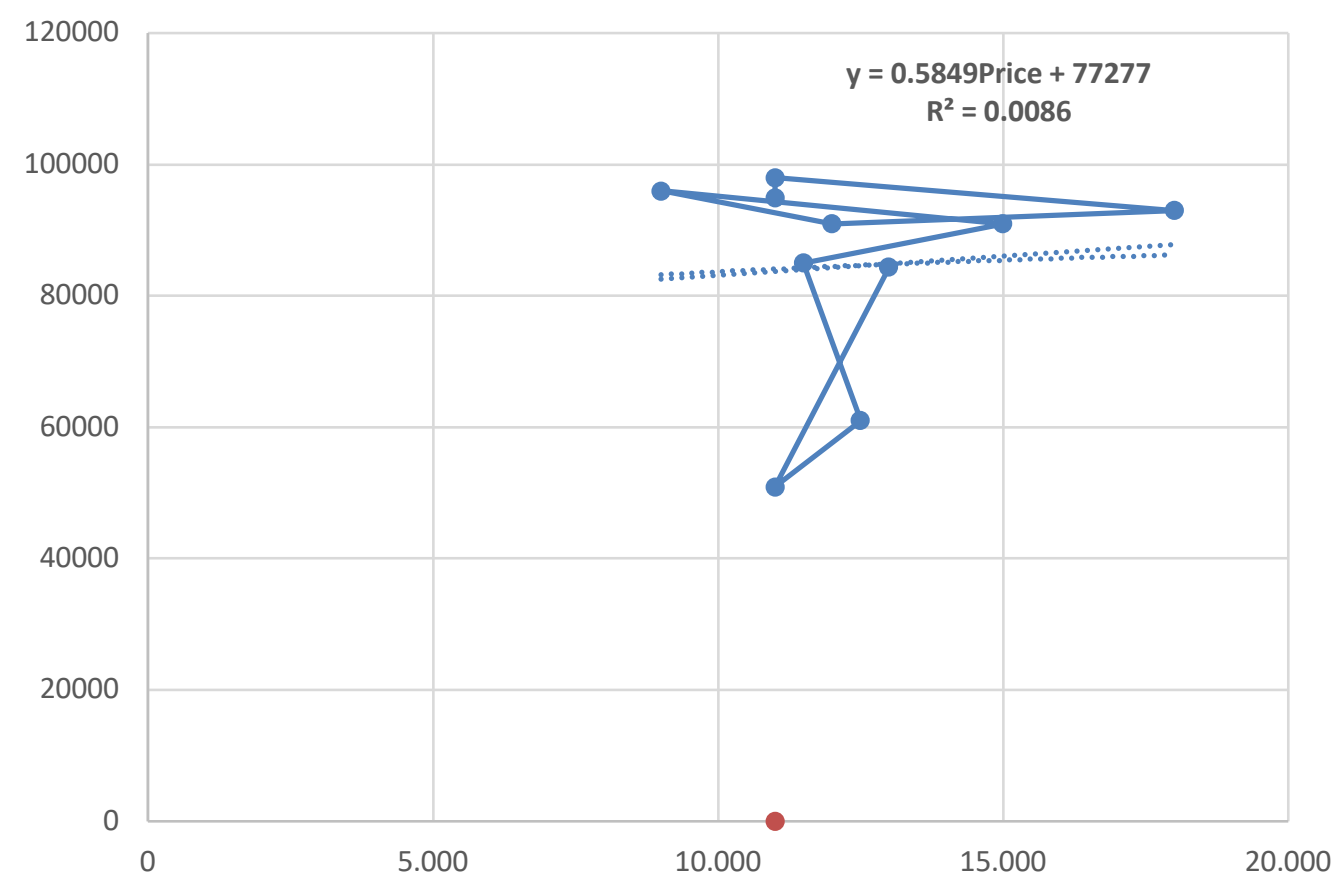

Figure 1: supply curve relation; Source: Tesla- statista (2018). Numbers are Price at vertical axis and Quantity at horizontal axis. 


\section{Demand Driving Forces}

Preference for new technologies: Vehicle technology is taking a whole new turn and there are a host of new technologies like hybrid vehicles, green cars, electric cars, battery operated cars and self-driven autonomous cars. Tesla has researched and launched many products in this emerging technology. With the trend towards environment friendly vehicles and regulations to limit emissions. Tesla has improved future opportunities in the battery electric vehicle (BEV) market. The price of the car is not a dominant factor, as we can see in figure 2, furthermore, the increasing preference for renewable energy lead to rising the popularity of low-carbon lifestyles and increasing preference for renewable energy. Moreover, Price of running cost: Price of oil and gasoline are skyrocketing, making the EV highly demanded. However, it is unsatisfying when you buy an expensive electric car and it expires after three years of use. The resident in the European countries can accept this concept but for others it may be inconvenient.

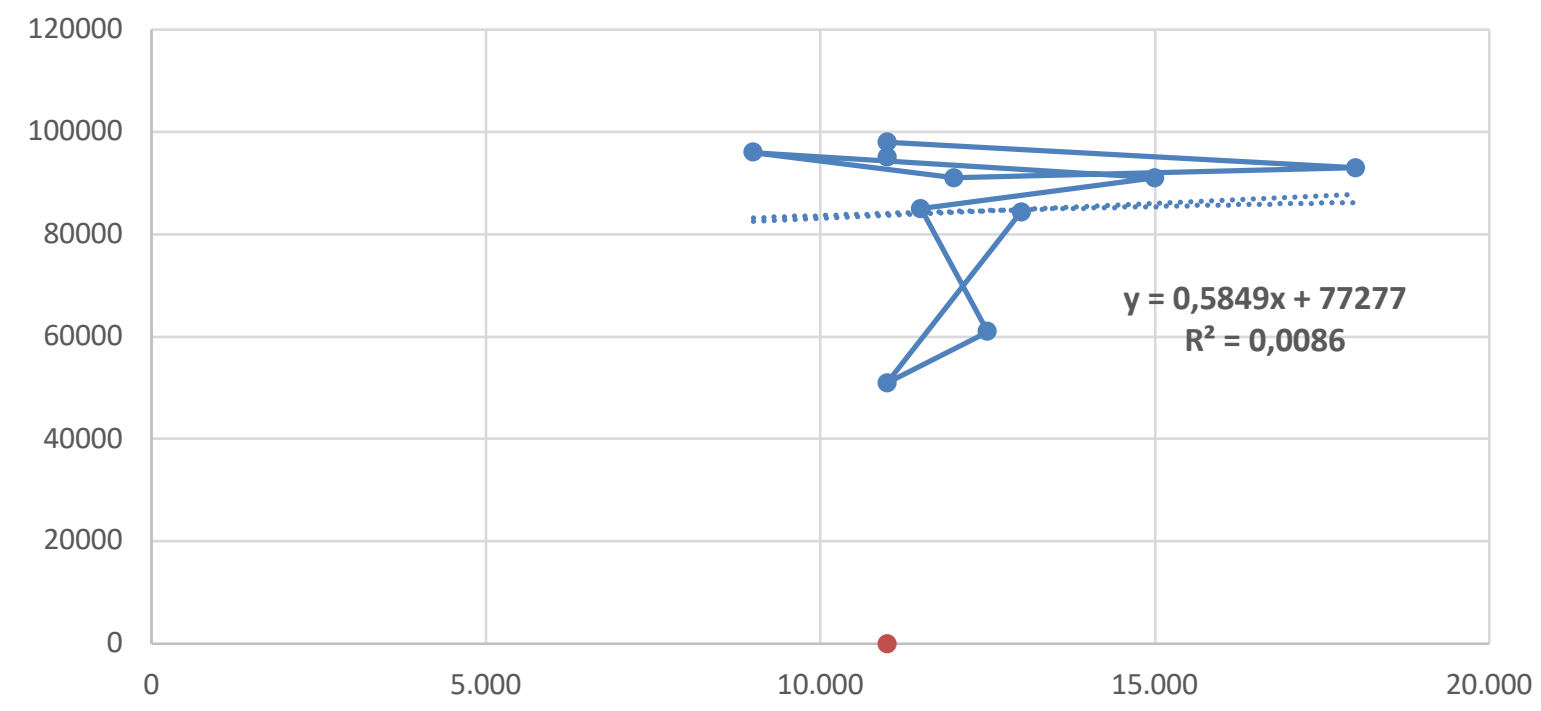

Figure 2: Demand Curve Relation; Source: Tesla- statista (2018). Numbers are Price at vertical axis and Quantity at horizontal axis.

Price elasticity

The following tanble represent the factor of the changes of elasticity during the period under study. The main factors was there is no substitutes in the market till the second quarter for 2017 and the penetration of the market till the end of 2017.

Table 1: demad elasticity

\begin{tabular}{llllllll}
\hline Period & Price & $\begin{array}{l}\text { Change } \\
\text { Price } \%\end{array}$ & $\begin{array}{l}\text { QTY } \\
\text { demanded }\end{array}$ & $\begin{array}{l}\text { Change } \\
\text { Demand } \\
\%\end{array}$ & Elasticity & Comment & Reasons affecting elasticity \\
\hline Q2 15 & $\$ 95,000$ & & 11,000 & & & & \\
\hline Q3 15 & $\$ 98,000$ & $3.11 \%$ & 11,000 & $0.00 \%$ & 0.00 & $\begin{array}{l}\text { Perfect } \\
\text { Inelastic }\end{array}$ & No availability of substitutes \\
\hline Q4 15 & $\$ 93,000$ & $-5.24 \%$ & 18,000 & $48.28 \%$ & -9.22 & Elastic & $\begin{array}{l}\text { Consumer preference for new } \\
\text { technology }\end{array}$ \\
\hline Q1 16 & $\$ 91,000$ & $-2.17 \%$ & 12,000 & $-40.00 \%$ & 18.40 & Elastic & Battery Performance issue - \\
\hline Q2 16 & $\$ 96,000$ & $5.35 \%$ & 9,000 & $-28.57 \%$ & -5.34 & Elastic & decline the units needed \\
\hline Q3 16 & $\$ 91,000$ & $-5.35 \%$ & 15,000 & $50.00 \%$ & -9.35 & Elastic & Increase costumer awareness \\
\hline Q4 16 & $\$ 85,000$ & $-6.82 \%$ & 11,500 & $-26.42 \%$ & 3.87 & Elastic & $\begin{array}{l}\text { Struggling in } \\
\text { infrastructure }\end{array}$ \\
\hline Q1 17 & $\$ 61,000$ & $-32.88 \%$ & 12,500 & $8.33 \%$ & -0.25 & Inelastic & Promotion \\
\hline Q2 17 & $\$ 50,950$ & $-17.95 \%$ & 11,000 & $-12.77 \%$ & 0.71 & Inelastic & New players in the market \\
\hline Q3 17 & $\$ 84,350$ & $49.37 \%$ & 13,000 & $16.67 \%$ & 0.34 & Inelastic & Market penetration in new states \\
\hline
\end{tabular}

Source: Tesla- statistics 2018 
On the other side the elasticity of supply as highly affected by the cost of production especially raw material and technology development and safety measures as see in table 2 .

Table 2: Supply elasticity

\begin{tabular}{llllllll}
\hline Period & Price & $\begin{array}{l}\text { Change } \\
\text { Price } \%\end{array}$ & $\begin{array}{l}\text { QTY } \\
\text { Produced }\end{array}$ & $\begin{array}{l}\text { Change } \\
\text { Supply } \%\end{array}$ & Elasticity & Comment & Reasons affecting elasticity \\
\hline Q2 15 & $\$ 95,000$ & & 11,532 & & & & \\
\hline Q3 15 & $\$ 98,000$ & $3.11 \%$ & 11,597 & $0.56 \%$ & 0.18 & Inelastic & No availability of substitutes \\
\hline Q4 15 & $\$ 93,000$ & $-5.24 \%$ & 17,272 & $39.32 \%$ & -7.51 & Elastic & Reduction of COGS \\
\hline Q1 16 & $\$ 91,000$ & $-2.17 \%$ & 12,420 & $-32.68 \%$ & 15.03 & Elastic & $\begin{array}{l}\text { Drop in stock price which affect the } \\
\text { supply }\end{array}$ \\
\hline Q2 16 & $\$ 96,000$ & $5.35 \%$ & 9,764 & $-23.95 \%$ & -4.48 & Elastic & Shortage in cash flow \\
\hline Q3 16 & $\$ 91,000$ & $-5.35 \%$ & 16,047 & $48.68 \%$ & -9.10 & Elastic & Production technology Advance \\
\hline Q4 16 & $\$ 85,000$ & $-6.82 \%$ & 12,700 & $-23.29 \%$ & 3.42 & Elastic & Product available in stock \\
\hline Q1 17 & $\$ 61,000$ & $-32.88 \%$ & 13,450 & $5.74 \%$ & -0.17 & Inelastic & Technology Advance \\
\hline Q2 17 & $\$ 50,950$ & $-17.95 \%$ & 12,000 & $-11.39 \%$ & 0.63 & Inelastic & Product available in stock \\
\hline Q3 17 & $\$ 84,350$ & $65.55 \%$ & 14,065 & $15.85 \%$ & 0.24 & Inelastic & Availability of Raw material
\end{tabular}

Source: Tesla- statistic 2018.

\section{Conclusions}

The electric vehicle market is considered as an 'emerging industry'. The emerging industry typically consists of just a few companies and it often depends on a new technology. Market type is oligopoly with few sellers with the same product and Tesla is the market leader in USA. Tesla has direct control over input prices mainly for battery cells, which will enable it to build battery electric vehicles with luxury standards in the price range of a midsize sedan. Worth mentioning that this product is an elastic one, see table 3 and 4.Tesla Model "S" market forces (demand and supply) is usually affected by other externalities and circumstances other than the price. Tesla Company spent on research for the improvement of their products and enhanced the supply to avoid losing market shares in front of its competitors.

Tesla will face an aggressive competition when giants like Mercedes and BMW enter the EV. The future prices will decrease drastically due to high competition. Tesla is a market leader in battery electric vehicles and will continue to lead in the near future as it has a dominant strategy referring to its' early technology adoptions, competitive price and mileage per charge. Customers will respond to incentives (prices), and hence they will have more alternatives starting 2020. However, one of the future challenges is the recycling of batteries and what will its' impact on the environment be.

\section{References}

Boyd, J. H., \& Mellman, R. E. (1980). The effect of fuel economy standards on the US automotive market: an hedonic demand analysis. Transportation Research Part A: General, 14(5-6), 367-378.

Cheong, T., Song, S. H., \& Hu, C. (2016). Strategic alliance with competitors in the electric vehicle market: Tesla motor's case. Mathematical Problems in Engineering, 2016.

Dragasevic, Z., Rakocevic, S., Glisevic, N., \& Montenegro, P. (2011, September). The application of the game theory to the oligopolistic market. In 15th International Research/Expert Conference 'Trends in the Development of Machinery and Associated Technology'TMT (2011) (pp. 12-18).

Gayathree, P. K., \& Samarasinghe, D. (2019). Green Stimuli Characteristics and Green Self-Identity Towards Ethically Minded Consumption Behavior with Special Reference to Mediating Effect of Positive and Negative Emotions. Asian Social Science, 15(7).

Gullen, A., \& Plungis, J. (2013). Statista. The Charleston Advisor, 15(2), 43-47.

Holdway, A. R., Williams, A. R., Inderwildi, O. R., \& King, D. A. (2010). Indirect emissions from electric vehicles: emissions from electricity generation. Energy \& Environmental Science, 3(12), 1825-1832.

Kessler, A. M. (2015). Elon musk says self-driving tesla cars will be in the us by summer. The New York Times, B1.

Palin, R., Johnston, V., Johnson, S., D'Hooge, A., Duncan, B., \& Gargoloff, J. I. (2012). The aerodynamic development of the tesla model s-part 1: Overview (No. 2012-01-0177). SAE Technical Paper. 
Parmar, C., Tiwari, S., Chauhan, A., Srivastava, S., \& Gangopadhyay, S. (2017). Tackle low frequency structural vibration in AMT car using gear shift schedule optimization (No. 2017-26-0198). SAE Technical Paper.

Somssich, E. (2017). Definition and Market Analysis of the Tesla Motors Model S. GRIN Verlag. Fuel elements in aquatic phases of repository host rock formations. Nuclear Engineering \& Design, 236, 54.

Stringham, E. P., Miller, J. K., \& Clark, J. R. (2015). Overcoming barriers to entry in an established industry: Tesla Motors. California Management Review, 57(4), 85-103.

Sun, J. (2010). Car battery efficiencies. Stanford University Course Work, Physics, 240, 100.

Tesla's net loss 2008-2017. (n.d.). Retrieved April 16, 2019, from https://www.statista.com/statistics/272130/net-loss-of-tesla 